\begin{tabular}{ll}
\hline \hline MINING AND METALLURGY INSTITUTE BOR & ISSN: 2334-8836 \\
UDK: 622 \\
\hline \hline
\end{tabular}

\title{
SELECTION OF THE OPTIMUM LOCATION OF THE PRIMARY ORE CRUSHING AT THE OPEN PIT SOUTH MINING DISTRICT USING THE COMPARATIVE ANALYSIS OF SIMULATION RESULTS OF THE TRUCK TRANSPORT
}

\begin{abstract}
This work presents the procedure of transport simulation at the Open Pit South Mining District for two locations of the primary ore crushing and comparison of the achieved capacities and consumption of normative material, in order to determine the optimum location. Simulation was performed using the haulage and loading simulation software, Talpac.
\end{abstract}

Keywords: simulation, Talpac, transport routes, location of primary crushing.

\section{INTRODUCTION}

Copper deposit the South Mining District - Majdanpek is located close to the town of Majdanpek in the basin of the river Mali Pek. The open pit South Mining District, where the exploitation begun in 1959, is located within the copper deposit South Mining District - Majdanpek. The infrastructural facilities are situated in the immediate vicinity of the deposit that are used for ore processing as well as the truck waste landfills and flotation tailing dump. The open pit South Mining District is located at a distance of $0,5 \mathrm{~km}$ from the open pit North Mining District, which is also located near the town of Majdanpek (Figure 1).

The Feasibility Study has defined the dynamics of exploitation of the copper ore deposit South Mining District, with the an nual capacity of ore mining of 8500000 t/year $[1,2]$. Dynamics of the Study has defined that only waste will be excavated in the first year in the operations Andesite Finger in the northwestern part of the open pit and the East in the eastern part of the open pit, while the ore will be excavated from the second year.

The primary ore crushing plant is located in the western side of the final contour of open pit, at elevation of $\mathrm{K}+375$, while the waste will be transported primarily to the external landfills and after repairing the transport system for waste, to the crushing plant of this system TS-1 [1.3]. The fragmented waste is transported by the transport systems TS-1 to the landfill Ujevac.

\footnotetext{
* Mining and Metallurgy Institute Bor, vedran.kostic@irmbor.co.rs
} 


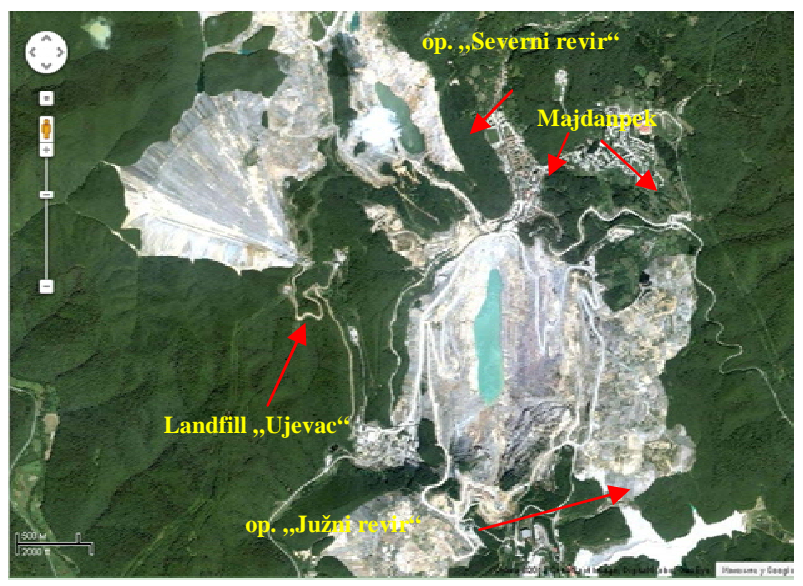

Figure 1 Satellite image of mining facilities near the town of Majdanpek

In addition to the above mentioned location of the ore crushing plant, there is a crushing plant located on the southern edge of the open pit North Mining District

within the so-called Phase 2, at elevation of $\mathrm{K}+433$ (Figure 2), which can be an alternative solution for ore crushing from the South Mining District.

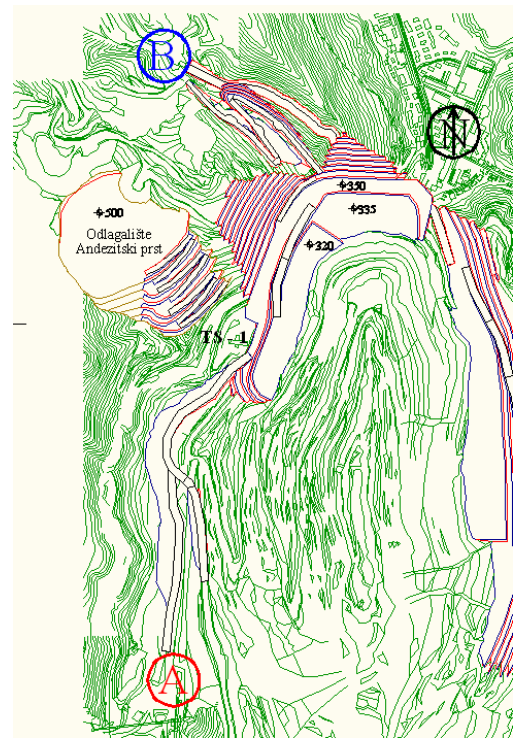

Figure 2 North-western mining lay-out of the open pit South Mining District with locations of the primary crushing: A - location provided by the Feasibility Study; B - location of Phase 2 near the open pit North Mining District

During mining operations in the Andesite Finger in the first year of excavation dynamics, disassembly of crusher was done in the western side of the open pit South Mining District and its relocation at the open pit Cerovo, in order to return the same on the study predicted location to the beginning of the second year of excavation dynamics.

However, due to a great possibility of delay in returning the crusher to the predicted location (A), an interim possible solution 
in such case is ore crushing on the crushing plant of "Phase 2" (B) in the North Mining District. The cost-effectiveness of such forced solution was also analyzed and by comparison of the operating costs of truck transportation of ore for two mentioned locations of the primary crushing.

For this purpose, the simulation of truck ore transport was done to the predicted location of the primary crushing (A) or to the location (B), i.e. Phase 2, using the haulage and loading simulation software Talpac and the results are presented for obtained exploitation capacities of truck, consumption of fuel, oil and greases and tires.

\section{Description of the technological processes and transport routes at the Open Pit South Mining District}

At the open pit South Mining District, a discontinuous mining technology is applied. Ore and overburden (waste) are prepared using the drilling-blasting works for loading with excavators whose bucket capacity is $15 \mathrm{~m}^{3}$ (TEREX O\&K - RH 120) and $22 \mathrm{~m}^{3}$ (KOMATSU DEMAG PC40006). Transport of excavated material is done by trucks, whose payloads are $136 \mathrm{t}$ (BELAZ 7513), $150 \mathrm{t}$ (KOMATSU HD 1500-5) and $220 \mathrm{k}$ (BELAZ 75306B). Transport routes, both at the open pit and external, are designed with maximum gradient not exceeding $8 \%$, due to the technical characteristics of the truck fleet $[2,4]$.

Figure 2 shows the mining layout of the north-western part of the open pit South Mining District (Andesite Finger) at the end of the second year of exploitation with a view of the primary crushing location. Label A represents the location of primary crushing that is provided by the Feasibility Study. Crushing plant at this location is at elevation $\mathrm{K}+375$. The average length of transport routes from the center of mass at the site is $2.06 \mathrm{~km}$ in the second year and $2.91 \mathrm{~km}$ in the third year. Label B represents the location of crushing plant on the southern edge of the open pit North Mining District, so called Phase 2. Crushing plant at this location is at elevation $\mathrm{K}+433$. The average length of transport routes from the site at the open pit South Mining District is $1.92 \mathrm{~km}$ in the second year and $2.57 \mathrm{~km}$ in the third year of exploitation.

Comparing the transport routes for the given locations, it can be seen that the transport routes have less length in the case of ore transport to the location B (Phase 2), but it is also evident that the height of lifting is greater $(\mathrm{K}+433)$ than it is the case with the location of $\mathrm{A}(\mathrm{K}+375)$. This can be seen in more detail in the following figures (Figures 3 and 4).

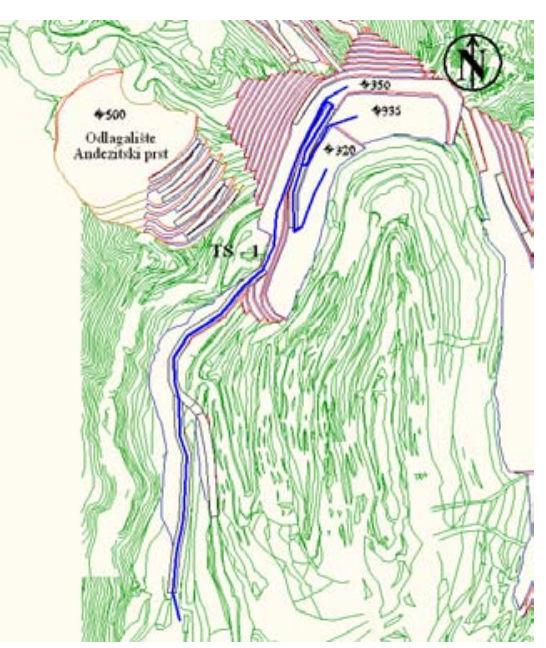

Figure 3 Mining layout of open pit South Mining District at the end of the second year with the presented transport route to the crushing plant (location A) 


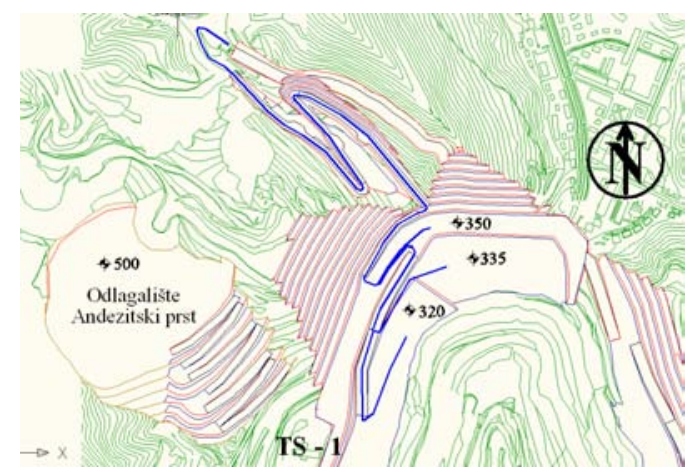

Figure 4 Mining layout of open pit South Mining District at the end of the second year with the presented transport route to the crushing plant Phase 2 (location B)

Description of the database structure of input data, simulation types of transport systems and methods of calculation of the fuel consumption in the software Talpac

Optimization of transport that is carried out in Talpac allows that changing of input parameters such as the type of material, organization of work, type of loading and transport equipment and characteristics of transport routes, can determine the optimal solution for transport system at the open pit the mine in terms of achievement of the lowest costs of this technological phase. This is achieved through the selection of appropriate equipment and transport routes which allow higher capacity, and hence smaller truck fleet and lower costs of consumables, out of which the most important is the fuel.

The structure of the input database of software Talpac defining loading-transport cycle is shown in the following diagram (Figure 5) [5,6].

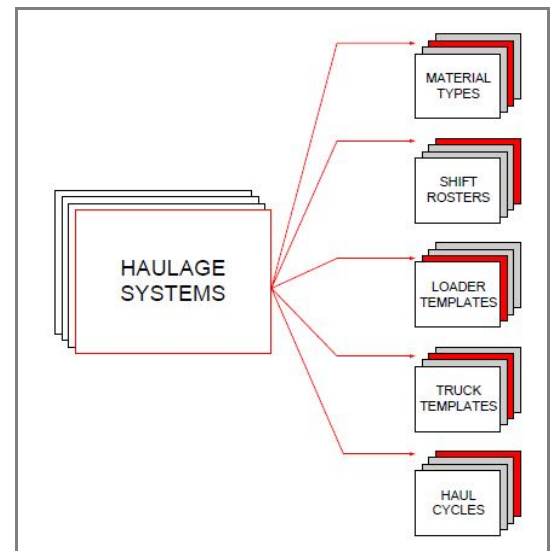

Figure 5 Structure of the database of software Talpac 
There are two types of simulation in Talpac, as follows: Full Simulation and Quick Estimate.

Full simulation is a stochastic model that takes into account variability of data used in calculation, such as: time of loading and transport cycle, unloading time of the truck, coefficient of filling the excavator bucket and truck load capacity. Variation of these data in transport cycle, through a certain number of shifts, results into possible loss of time due to the truck waiting in line for loading or inactivity of the excavator due to the truck waiting, which finally affects the productivity of loading-transport system.
In contrast to the Full Simulation, the Quick Estimate is a deterministic model that does not take into account the variability of the above-mentioned data and therefore the obtained result is for the ideal case.

In the case of transport simulation at the open pit South Mining District, the method of Full Simulation was used.

Calculation of fuel consumption in Talpac is carried out over the trucks engine load (rimpull - traction force) that occurs in a particular segment of the transport cycle, depending on the speed of truck movement in this segment (Figure 6). This load depends on the material weight that is transported and the roads grade.

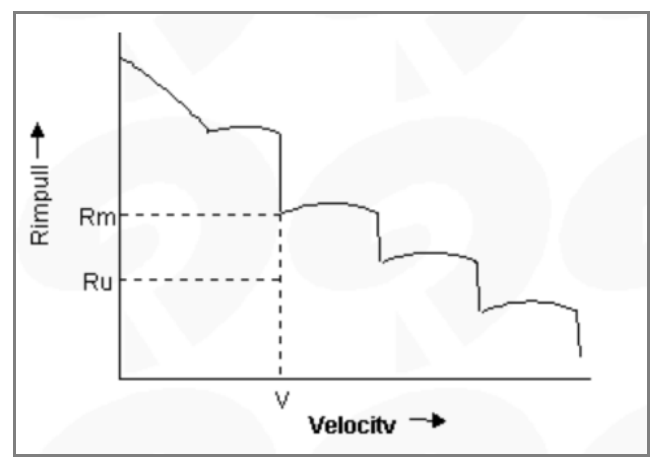

Figure 6 Ratio of traction force ("rimpull") and speed of truck movement: $R_{m}$ - maximum possible traction force for the achieved speed of movement in a particular segment; $R_{U}$ - generated traction force for the achieved speed of movement in a particular segment; $v$-speed of truck movement

Fuel consumption on a particular segment is calculated using the formula [7]:

$$
\Delta f=\left[\frac{R_{U}}{R_{m}} \times \frac{\left(F_{100}-F_{0}\right)}{60}\right] \times \Delta t
$$

where:

$\Delta f$ - spent fuel on a particular segment (l),

$R_{U} / R_{m}$ - ratio of generated and maximum traction force for the achieved speed at a particular segment,

$F_{100}$ - fuel consumption at $100 \%$ utilization of engine power $(1 / \mathrm{h})$,
$F_{0}$ - fuel consumption when operating "at idle", exp. truck waiting to be loaded $(\mathrm{l} / \mathrm{h})$,

$\Delta t$ - time of truck movement in a particular segment.

Fuel consumption in each segment, cumulatively represents total fuel consumption for transport route. The average hourly fuel consumption is given by the following formula [7]:

$$
F=\left(f_{t} \times N_{\text {trips }}\right)+\left[60-\left(N_{\text {trips }} \times T_{\text {travei }}\right) \times \frac{F_{0}}{60}\right]
$$


where:

$F$ - average hourly fuel consumption (1/h),

$f_{t}$ - total fuel consumption for transport route (1),

$\mathrm{N}_{\text {trips }}$ - number of transport cycles per hour,

$\mathrm{T}_{\text {travel }}$ - time of transport cycle (min).

\section{Simulation of truck transport depending on the location of primary crushing}

Simulation of truck transport is carried out using the software Talpac for the first two years of ore excavation, i.e. for the second and third year according to the defined dynamics of ore excavation.

Simulation was performed with the following input data:

- data for the ore are taken for material, i.e. density of $2.65 \mathrm{t} / \mathrm{m}^{3}$,
- 5,688 $\mathrm{h} /$ year is taken for the working time at the open pit (Roster), i.e. $5,206 \mathrm{~h} /$ year for transport mechanization,

- transport route (Haul Cycle) is defined by entering the segments of appropriate lengths, slope, curve turns and the average speed of truck at the open pit (Figure 7),

- TEREX O\&K - RH 120 excavator with bucket volume of $15 \mathrm{~m}^{3}$ was chosen as a loading mechanization for ore in these years,

- BELAZ 7513 trucks, loading capacity of 136 t, KOMATSU HD 1500-5, loa-ding capacity of $150 \mathrm{t}$ and BELAZ 75306B, loading capacity of $220 \mathrm{t}$, were chosen as a transport mechanization.

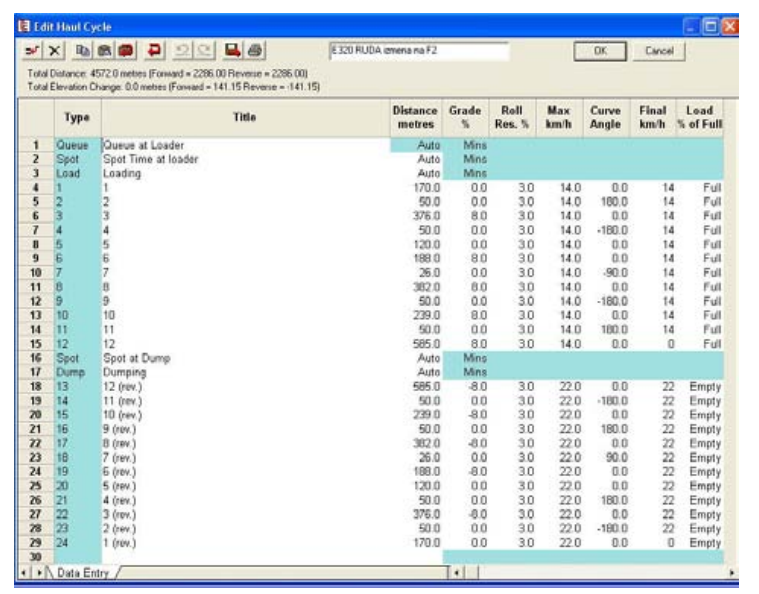

Figure 7 Entering the segments of a transport route for level E320

Figure 7 shows the transport cycle (Haul Cycle) for level E320 which consists of a loading cycle, a cycle of driving the full truck and unloading cycle, and also in the opposite direction to the movement of the empty truck, at the transport route which is incorporated in segments.

The result of calculation is significantly affected by exploitation-technical characteristics of selected equipment. These characteristics are a part of the standard database in Talpac that are used by the program in calculation. Talpac has a database of a large number of trucks that are in use, and if the truck is not in the database, there is a possibility of addition for new mechanization.

Figure 8 shows a diagram of ratio of the traction forces that are created during the truck movement and speed of movement in the case of a truck KOMATSU HD 1500-5, loading capacity $150 \mathrm{t}$. Diagram (taken 
from the Talpac database) shows a logical trend of decreasing the speed of truck movement with the increase of load in movement. Through these data, the pro gram determines achievable truck speeds in the segments of transport routes that are uphill, what ultimately affects the exploitation capacity of truck.

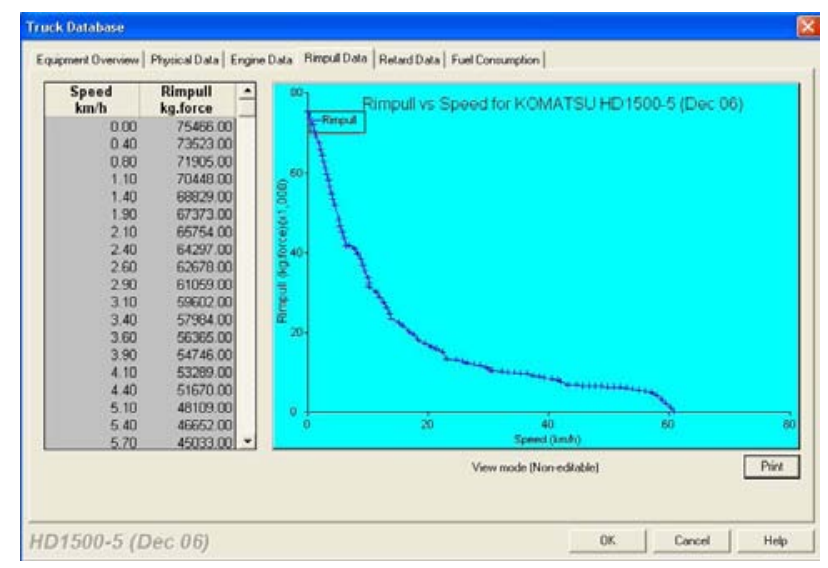

Figure 8 Ratio of traction forces and movement speeds for KOMATSU HD 1500-5 truck

Figure 9 shows a graph showing the dependence of fuel consumption on the loads in truck movement. Fuel consumption is calculated by the specific fuel consumption, which is taken from the manufacturer and recorded in the table (the upper left corner of Figure 9), taking into account the engine load of truck in movement, i.e. uphill vs. downhill movement.

As it can be seen from the diagram in Figure 9, the fuel consumption decreases during deceleration (downhill movement), or increases in acceleration of truck (uphill movement).

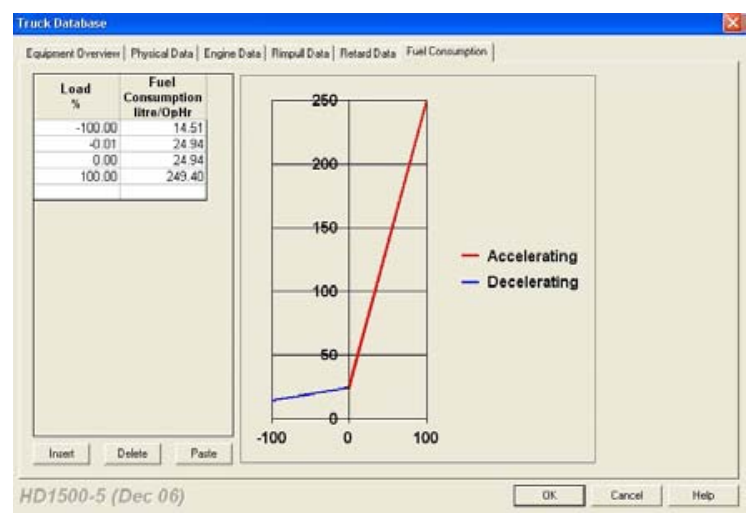

Figure 9 "Window" for data entering on fuel consumption

Based on the entered data on fuel consumption in a particular operation mode of truck engine, the program calculates the fuel consumption for the considered route. 


\section{Simulation results}

Figure 10 shows the results of simulations for specific level (in this case the level E320), i.e. the exploitation capacity of truck and fuel consumption for this transport route. Consumption of oil and

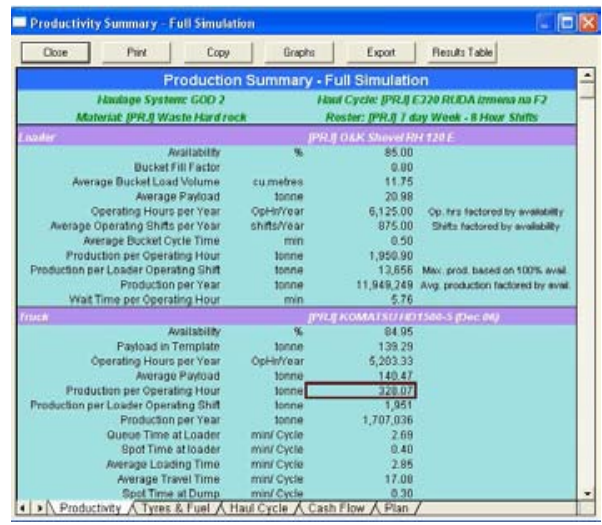

a) grease is adopted as $10 \%$ of fuel consumption, while the consumption of tires is calculated depending on the resulting exploitation capacity and lifetime of the tires, which is adopted as 4,800 Mh.

Figure 10 Simulation results : a) - exploitation capacity, $b$ ) - fuel consumption

Table 1 shows an example of transport calculation for the second year of operation, in the case of ore transport to the crushing plant of Phase 2 (location B). The operational capacity and consumables are calculated for each route (level) separately, while for the final results of this year, the average weighted values are taken. The required number of trucks is obtained by dividing the planned annual production of ore and the annual capacity of one truck.

In the second year, due to lower volumes of ore, the simulation is only performed for trucks KOMATSU, loading capacity of 150 t. The Copper Mine Majdanpek (RBM) has 2 trucks of this type which satisfies the required number of trucks obtained by calculation.

In the third year occur large amounts of ore, and therefore require a large number of trucks. Simulation for this year was made taking into account the known number of trucks that RBM has, i.e. 2 trucks KOMATSU, loading capacity $150 \mathrm{t}$, and 3

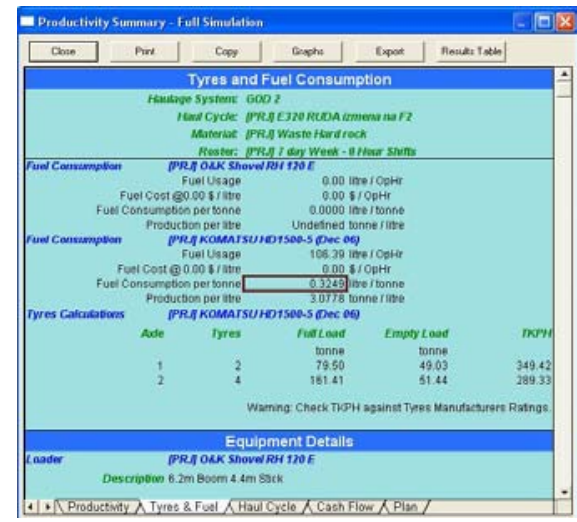

b)

trucks BELAZ, loading capacity $136 \mathrm{t}$, where the unknown (necessary) number of trucks BELAZ, loading capacity $220 \mathrm{t}$, is added which is required to meet the designed capacity. The result of calculation has shown that in addition to the known number of trucks, loading capacities $136 \mathrm{t}$ and $150 \mathrm{t}$, another one truck, loading capacity $220 \mathrm{t}$, is required in order to achieve the planned capacity of transport, i.e. the total number of required trucks is 6 . Method of calculation for the third year in the case of ore transport to Phase 2, is shown in Table 2. Exploitation capacity and consumables per levels, shown in Table 2, represent the average weighted values of the obtained results for individual trucks.

Method of calculation for the second location of crushing (location A) in the second and third year is the same to the shown one in Tables 1 and 2, so there is no need for a table view for this location, however the final results for this location will be shown in Table 3. 
Table 3 presents the comparative results for the second and third year of the excavation dynamics for the locations of primary crushing $\mathrm{A}$ and $\mathrm{B}$. Due to the shorter transport routes for location B (Phase 2), a slightly higher exploitation capacity is ob tained and thus lower consumption of tires. On the other hand, due to the need for dealing with a large elevation difference for this location, the fuel consumption is increased. The required number of trucks in these two cases, for these two years, has not changed.

Table 1 Results of calculation for the SECOND year for ore transport to Phase 2 (location B)

\begin{tabular}{|c|c|c|c|c|c|c|c|c|c|c|c|}
\hline Feedback & Year & Level & Oret & $t / h$ & h/year & $\begin{array}{l}\text { No. of } \\
\text { trucks }\end{array}$ & $\begin{array}{c}\text { Route } \\
\text { length } \\
\quad \mathrm{km}\end{array}$ & $t k m$ & $\begin{array}{c}O i l, \\
l / t\end{array}$ & $\begin{array}{c}\text { Oil \& } \\
\text { grease, } \\
\quad l / t\end{array}$ & $\begin{array}{l}\text { Tires, } \\
\text { tires/t }\end{array}$ \\
\hline 1 & 2 & 3 & 4 & 5 & 6 & 7 & 8 & 9 & 10 & 11 & 12 \\
\hline \multirow{6}{*}{$\begin{array}{c}\text { Excavator } \\
15 \mathrm{~m}^{3}- \\
\text { Truck } 150 \\
t\end{array}$} & \multirow{5}{*}{2.} & E380 & 27732 & 464.94 & 5206 & 0.01 & 1.441 & 39961 & 0.2157 & 0.02157 & 0,0000021 \\
\hline & & E365 & 551537 & 478.78 & 5206 & 0.2 & 1.368 & 754503 & 0.2103 & 0.02103 & 0,0000020 \\
\hline & & E350 & 1104511 & 398.96 & 5206 & 0.5 & 1.735 & 1916327 & 0.2536 & 0.02536 & 0,0000024 \\
\hline & & E335 & 1526107 & 339.97 & 5206 & 0.9 & 2.128 & 3247555 & 0.2994 & 0.02994 & 0,0000028 \\
\hline & & E320 & 575510 & 327.44 & 5206 & 0.3 & 2.286 & 1315616 & 0.3250 & 0.0325 & 0,0000029 \\
\hline & \multicolumn{2}{|c|}{ Total } & 3785397 & 376,418 & 5206 & 1.9 & 1.9216 & 7273963 & 0.2763 & 0.02763 & 0.0000026 \\
\hline
\end{tabular}

Table 2 Results of calculation for the THIRD year for ore transport to Phase 2 (location B)

\begin{tabular}{|c|c|c|c|c|c|c|c|c|c|c|c|}
\hline Feedback & Year & Level & Oret & $t / h$ & h/year & $\begin{array}{l}\text { No. of } \\
\text { trucks }\end{array}$ & $\begin{array}{c}\text { Route } \\
\text { length } \\
\mathrm{km}\end{array}$ & tkm & $\begin{array}{c}\text { Oil, } \\
l / t\end{array}$ & $\begin{array}{c}\text { Oil \& } \\
\text { grease, } \\
\quad l / t\end{array}$ & $\begin{array}{l}\text { Tires, } \\
\text { tires } / t\end{array}$ \\
\hline 1 & 2 & 3 & 4 & 5 & 6 & 7 & 8 & 9 & 10 & 11 & 12 \\
\hline \multirow{7}{*}{$\begin{array}{c}\text { Excava- } \\
\text { tor } 15 \mathrm{~m}^{3} \\
- \text { Trucks } \\
136 \mathrm{t} \\
150 \mathrm{t} \\
\text { and } 220 \mathrm{t}\end{array}$} & \multirow{6}{*}{3.} & E320 & 1022074 & 313.637 & 5206 & 0.5 & 2.511 & 2566428 & 0.3071 & 0.03071 & 0.0000031 \\
\hline & & E305 & 1607407 & 276.520 & 5206 & 1.1 & 2.874 & 4619689 & 0.3532 & 0.03532 & 0.0000035 \\
\hline & & E290 & 1665957 & 276.153 & 5206 & 1.2 & 2.847 & 4742979 & 0.3640 & 0.03639 & 0.0000035 \\
\hline & & E275 & 1691960 & 269.713 & 5206 & 1.2 & 2.89 & 4889765 & 0.3857 & 0.03856 & 0.0000036 \\
\hline & & E260 & 1672198 & 254.543 & 5206 & 1.3 & 3.103 & 5188831 & 0.4192 & 0.04192 & 0.0000038 \\
\hline & & E245 & 875609 & 244.910 & 5206 & 0.7 & 3.261 & 2855.362 & 0.4492 & 0.04491 & 0.0000039 \\
\hline & \multicolumn{2}{|c|}{ Total } & 8535206 & 271,995 & 5206 & 6.0 & 2.91 & 24863055 & 0.3790 & 0.03790 & 0.0000035 \\
\hline
\end{tabular}

Table 3 Comparative review of the results for both locations of primary ore crushing for various types of trucks

\begin{tabular}{|c|c|c|c|c|c|c|c|c|}
\hline $\begin{array}{l}\text { Year / } \\
\text { period }\end{array}$ & $\begin{array}{l}\text { Loading- } \\
\text { transport } \\
\text { feedback }\end{array}$ & $\begin{array}{c}\text { Location of } \\
\text { the crushing } \\
\text { plant }\end{array}$ & $\begin{array}{l}\text { Average } \\
\text { length of } \\
\text { route, } \mathrm{km}\end{array}$ & $\begin{array}{c}\text { Average } \\
\text { hourly } \\
\text { exploitation, } \\
\text { capacity, } t / h\end{array}$ & $\begin{array}{c}\text { Fuel } \\
\text { consump. } \\
\text { l/t }\end{array}$ & $\begin{array}{c}\begin{array}{c}\text { Oil and } \\
\text { grease } \\
\text { consump. } \\
l / t\end{array} \\
\end{array}$ & $\begin{array}{c}\text { Tire } \\
\text { consump., } \\
\text { tires } / t\end{array}$ & $\begin{array}{l}\text { Required } \\
\text { Number } \\
\text { of trucks }\end{array}$ \\
\hline \multirow{2}{*}{ Year 2.} & \multirow{2}{*}{$\begin{array}{l}\text { Excavator } \\
15 \mathrm{~m}^{3}- \\
\text { Trucks150 t }\end{array}$} & $\mathbf{A}$ & 2.06 & 359.23 & 0.2082 & 0.02082 & 0.0000027 & 2 \\
\hline & & B & 1.92 & 376.42 & 0.2763 & 0.02763 & 0.0000026 & 2 \\
\hline \multirow[b]{2}{*}{ Year 3.} & \multirow{2}{*}{$\begin{array}{l}\text { Excavator } \\
15 \mathrm{~m}^{3}-\text { Trucks } \\
136 \mathrm{t}, 150 \mathrm{t} \\
\text { and } 220 \mathrm{t}\end{array}$} & $\mathbf{A}$ & 2.91 & 271.95 & 0.3790 & 0.03790 & 0.0000035 & 6 \\
\hline & & B & 2.57 & 280.25 & 0.3927 & 0.03927 & 0.0000034 & 6 \\
\hline
\end{tabular}

*In Tables 1 and 2 , in columns 5 and 10 - exploitation capacity $(t / h)$ and fuel consumption $(1 / t)$ for the route on the certain level, the results are given from the analysis in Talpac, while the other data are partly input (ore quantities), and partly derived by weighting and calculated on the basis of the results from the simulation in Talpac. For example: number of trucks for a certain level is calculated as a multiplication of columns 5 and 6 , divided by column 4 , i.e. $(5 * 6) / 4$. 


\section{CONCLUSION}

Applying the classical calculation method of transport, which does not take into account the characteristics of transport routes, for short transport route higher exploitation capacities would also be obtained but, on the other hand, also smaller values of consumables which is not the case here.

Using the haulage and loading simulation software, in this case the software Talpac, it is possible to make a decision based on more accurate obtained results than it is the case in using the conventional method of calculation. Also, once a simulation can be performed, it can be recalculated many times by changing the input parameters such as the type of loading and transport equipment, transport routes, speed of truck movement and planned organization of work.

On the other hand, to exploit the possibility of obtaining more precise simulation results, it is necessary to process the transport routes in detail, i.e. to enter into segments for each uphill, downhill and turn. This increases the time required for the calculation of transport compared to the classical method in which this is usually not done.

\section{REFERENCES}

[1] D. Kržanović et al.: Feasibility Study on Mining the South Mining District Deposit in the Copper Mine Majdanpek, Mining and Metallurgy Institute Bor, 2011;

[2] D. Kržanović, M. Žikić, N. Vušović, R. Pantović, S. Stojadinović: Optimum Development of the Open pit South Mining District in Majdanpek for
Annual Capacity of Copper Ore Mining of $8500000 \mathrm{t}, 44^{\text {rd }}$ International October Conference on Mining and Metallurgy, Hotel Albo Bor, 1-3 October 2012; pp. 225-228

[3] D. Kržanović, M. Žikić, R. Pantović: Important Improvement of Utilization the Available Geological Reserves of the South Mining District Deposit in Majdanpek in the New Defined Optimum Contour of the Open Pit Using the Whittle and Gemcom Software, Mining Engineering, 1/2012, pp. 29-36;

[4] D. Kržanović, M. Žikić, S. Stojadinović: Analysis of the Realized and Catalog Fuel Consumption of Trucks Belaz 7530b in the First Year of Exploitation at the Open Pit Veliki Krivelj Serbia, Integrated International Symposium Tiorir, '11, Proceedings, Volume 1, Zlatibor, Serbia, 11-15 September 2011, pp. 60-64;

[5] V. Malbašić, J. Hamović: Economic Evaluation of Haulage System Shovel - Truck at the Open Pit Mines, The International Journal of Transport and Logistics, Issue 7, pp. 17-31, 2004;

[6] R. Janković, Lj. Savić: Simulation of Truck Haulage at the Open Pit Mine Majdanpek, Transport and Logistics, Issue 11, pp. 96-103, 2006;

[7] Talpac Manual: TALPAC Truck and Loader Productivity Analysis, Release 9, 2007.

[8] S. Mašić, M. Brčaninović, Analysis the Operating Parameters of БелА3 Truck at the Open Pits of the Brown Coal Mine "Banovici" Based on Processor Data, Mining and Metallurgy Institute Bor, 4/2013, pp. 29-38. 


\begin{tabular}{ll}
\hline \hline INSTITUT ZA RUDARSTVO I METALURGIJU BOR & ISSN: 2334-8836 \\
& UDK: 622 \\
\hline \hline
\end{tabular}

Vedran Kostić, Zoran Vaduvesković, Daniel Kržanović*

\section{IZBOR OPTIMALNE LOKACIJE PRIMARNOG DROBLJENJA RUDE NA POVRŠINSKOM KOPU JUŽNI REVIR UPOREDNOM ANALIZOM REZULTATA SIMULACIJE KAMIONSKOG TRANSPORTA}

Izvod

Ovim radom je prikazan postupak simulacije transporta na površinskom kopu Južni revir za dve lokacije primarnog drobljenja rude i upoređivanje postignutih kapaciteta i potrošnje normativnog materijala, u cilju određivanja optimalne lokacije. Simulacija je izvršena softverom za simulaciju utovarno transportnih sprega Talpac.

Ključne reči: simulacija, Talpac, transportna relacija, lokacija primarnog drobljenja.

\section{UVOD}

Ležište bakra Južni revir - Majdanpek nalazi se u neposrednoj blizini grada Majdanpekau slivu reke Mali Pek. U okviru ležišta bakra Južni revir - Majdanpek nalazi se površinski kop Južni revir, u kome je eksploatacija počela 1959. godine. U neposrednoj okolini ležišta nalaze se infrastrukturni objekti koji se koriste za preradu rude, kao i kamionska odlagališta jalovine i flotacijsko odlagalište. Od površinskog kopa Severni revir, koji se takođe nalazi u blizini grada Majdanpeka, površinski kop Južni revir udaljen je oko $0,5 \mathrm{~km}$ (slika 1 ).

Studijom izvodljivosti definisana je dinamika eksploatacije ležišta rude bakra Južni revir, sa godišnjim kapacitetom otkopavanja na rudi od $8.500 .000 \mathrm{t} / \mathrm{god}$ $[1,2]$. Dinamikom Studije je definisano da će se u prvoj godini otkopavati isključivo jalovina u zahvatima Andezitski prst u severozapadnom delu kopa i Istok u istočnom delu kopa, dok će se ruda otkopavati počev od druge godine.

Postrojenje primarnog drobljenja za rudu je locirano u zapadnom boku završne konture kopa, na koti $\mathrm{K}+375$, dok ce se jalovina transportovati najpre na spoljna odlagališta i nakon reparacije transportnog sistema za jalovinu, do drobiličnog postrojenja ovog sistema TS-1 [1,3]. Transportnim sistemom TS-1 usitnjena jalovina se transportuje na odlagalište Ujevac.

\footnotetext{
* Institut za rudarstvo i metalurgiju Bor, e-mail: vedran.kostic@irmbor.co.rs
} 


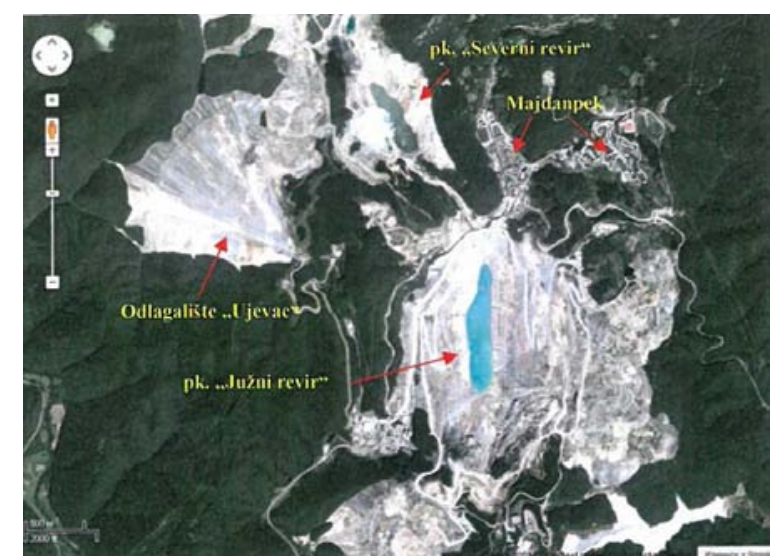

SI. 1. Satelitski snimak rudarskih objekata u blizini grada Majdanpeka

Pored pomenute lokacije drobljenja rude, postoji i drobilično postrojenje koje se nalazi na južnom obodu površinskog kopa Severni revir u sklopu tzv. Faze 2, na koti K+433 (slika 2) koje može biti alternativno rešenje i za drobljenje rude sa Južnog revira.

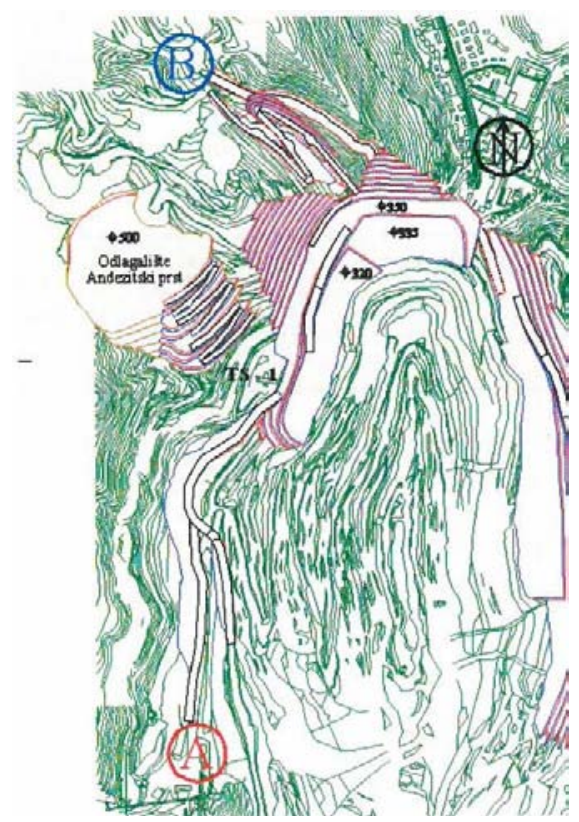

SI. 2. Severo-zapadni zahvat kopa Južni revir sa lokacijama primarnog drobljenja:

A - lokacija predviđena Studijom izvodljivosti; B - lokacija Faze 2 u blizini p. k. Severni revir

Za vreme odvijanja rudarskih radova na Andezitskom prstu $\mathrm{u}$ toku prve godine dinamike otkopavanja, izvršena je demontaža drobilice u zapadnom boku p. k. Južni revir i njeno izmeštanje na p. k. Cerovo, sa ciljem da se ista vrati na Studijom predvi- đenu lokaciju do početka druge godine dinamike otkopavanja.

Međutim, zbog postojanja velike mogućnosti kašnjenja sa vraćanjem drobilice na predviđenu lokaciju (A), moguće prelazno rešenje u takvom slučaju je drobljenje rude 
na drobiličnom postrojenju „Faze 2“ (B) na Severnom reviru. Isplativost ovakvog iznuđenog rešenja analizirana je i upoređenjem eksploatacionih troškova kamionskog transporta na rudi za pomenute dve lokacije primarnog drobljenja.

U tu svrhu izvršena je simulacija kamionskog transporta rude do predviđene lokacije primarnog drobljenja (A), odnosno do lokacije (B), tj. Faze 2, primenom softvera za simulaciju utovarno-transportnih sprega Talpac i prikazani su rezultati dobijenih eksploatacionih kapaciteta kamiona, potrošnje goriva, ulja i maziva i guma.

\section{Opis tehnoloških procesa i transportnih relacija na površinskom kopu Južni revir}

Na površinskom kopu Južni revir primenjuje se diskontinualna tehnologija otkopavanja. Ruda i raskrivka (jalovina) se bušačko-minerskim radovima priprema za utovar bagerima čije su zapremine kašika $15 \mathrm{~m}^{3}$ (TEREX O\&K - RH 120) i $22 \mathrm{~m}^{3}$ (KOMATSU DEMAG PC4000-6). Transport iskopina se vrši kamionima nosivosti 136 t (BELAZ 7513 ), 150 t (KOMATSU HD 1500-5) i 220 t (BELAZ 75306B). Transportni putevi, kako u kopu tako i spoljni, su projektovani sa maksimalnim nagibom koji ne prelazi 8\%, zbog tehničkih karakteristika dela kamionske flote $[2,4]$.

$\mathrm{Na}$ slici 2 data je situacija u severnozapadnom delu površinskog kopa Južni revir (Andezitski prst) na kraju druge godine eksploatacije sa prikazom lokacija primarnog drobljenja. Oznaka A predstavlja lokaciju primarnog drobljenja koja je predviđena Studijom izvodljivosti. Drobilično postrojenje na ovoj lokaciji se nalazi na koti $\mathrm{K}+375$. Prosečna dužina transportnih relacija od centra masa na radilištu je $2,06 \mathrm{~km} \mathrm{u}$ drugoj godini i 2,91 km u trećoj godini. Oznaka B predstavlja lokaciju drobiličnog postrojenja na južnom obodu površinskog kopa Severni revir, tzv. Faza 2. Drobilično postrojenje na ovoj lokaciji se nalazi na koti $\mathrm{K}+433$. Prosečna dužina transportnih relacija od radilišta na kopu Južni revir je 1,92 km u drugoj godini i 2,57 km u trećoj godini eksploatacije.

Upoređenjem transportnih relacija za navedene lokacije, vidi se da transportne relacije imaju manju dužinu u slučaju transporta rude prema lokaciji B (Faza 2), ali je takođe uočljivo da je visina dizanja veća $(\mathrm{K}+433)$ nego što je to slučaj sa lokacijom A $(\mathrm{K}+375)$. Ovo se može detaljnije videti na narednim slikama (slike 3 i 4).

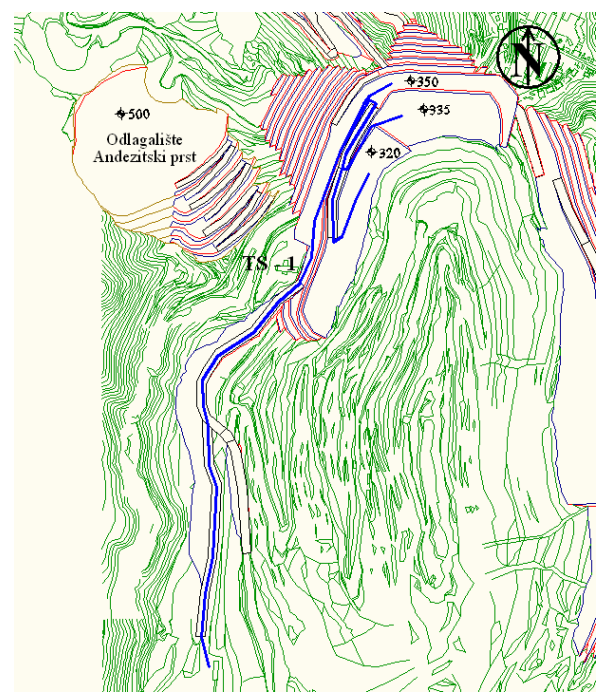

Sl. 3. Prikaz površinskog kopa „Južni revir" na kraju druge godine sa prikazanom transportnom relacijom do drobiličnog postrojenja (lokacija A) 


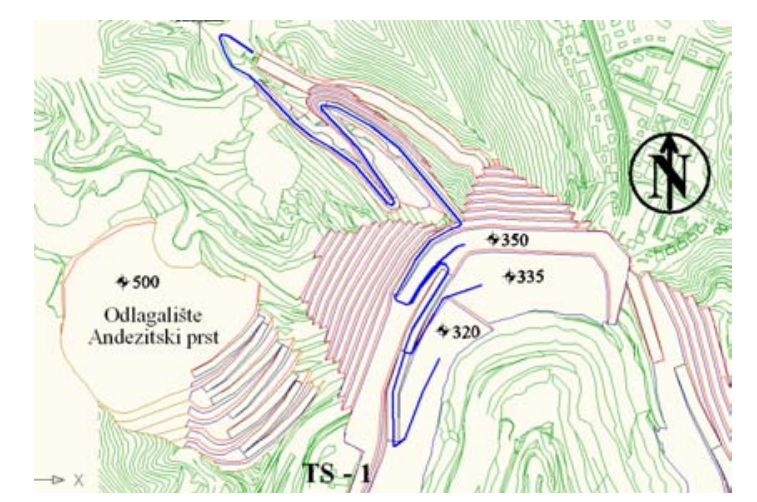

Sl. 4. Prikaz površinskog kopa „Južni revir“ na kraju druge godine sa prikazanom relacijom do drobiličnog postrojenja ,Faza 2“ (lokacija B)

\section{Opis strukture baze ulaznih podataka, tipova simulacije transportnih sistema $i$ načina proračuna potrošnje goriva $u$ softveru Talpac}

Optimizacija transporta koja se izvodi u Talpaku omogućuje da se promenom ulaznih parametara poput vrste materijala, organizacije rada, vrste utovarne i transportne opreme i karakteristika transportne relacije, odredi optimalno rešenje za transportni sistem na kopu u smislu postiznja najnižih troškova ove tehnološke faze. Ovo se postiže kroz izbor adekvatne opre- me i transportnih relacija koje omogućuju veći kapacitet, a time i manju kamionsku flotu i niže troškove normativnog materijala, od kojih je najznačajnije gorivo.

Struktura baze ulaznih podataka softvera Talpac kojom se definiše utovarno - transportni ciklus je prikazana na sledećoj šemi (slika 5) [5,6].

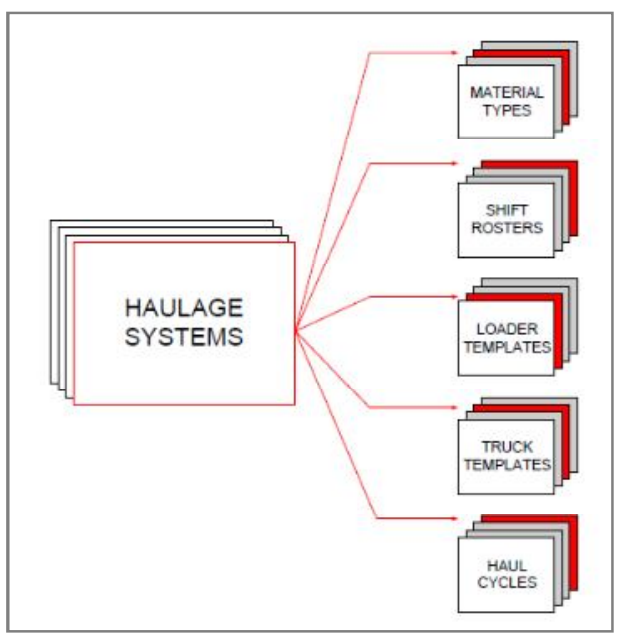

Sl. 5. Struktura baze podataka sofvera Talpac 
U Talpaku postoje dva tipa simulacije i to: Full Simulation (potpuna simulacija) i Quick Estimate (brza procena).

Potpuna simulacija predstavlja stohastički model i uzima u obzir varijabilnost podataka koji se koriste u proračunu, poput: vremena utovarnog i transportnog ciklusa, vreme istovara kamiona, koeficijent punjenja bagerske kašike i nosivost kamiona. Varijacija ovih podataka $\mathrm{u}$ transportnom ciklusu, kroz određeni broj smena, dovodi do mogućeg gubitka vremena zbog čekanja kamiona $\mathrm{u}$ redu na utovar ili neaktivnost bagera zbog čekanja na kamion, što konačno utiče na produktivnost utovarno - transportnog sistema.
Za razliku od potpune simulacije, simulacija Quick Estimate predstavlja deterministički model koji ne uzima u obzir varijabilnost pomenutih podataka i samim tim dobijeni rezultat je za idealni slučaj.

U slučaju simulacije transporta na površinskom kopu Južni revir korišćena je metoda Full Simulation.

Proračun potrošnje goriva se u Talpaku izvodi preko optrerećenja motora kamiona (rimpull - vučna sila) koje se javlja na određenom segmentu transportnog ciklusa $u$ zavisnosti od brzine kretanja kamiona na tom segmentu (slika 6). Ovo opterećenje zavisi od težine materijala koji se prevozi i od nagiba puta.

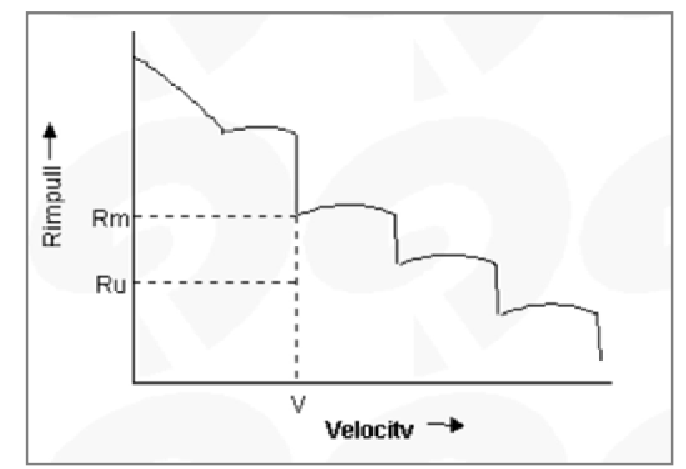

SI. 6. Odnos vučnih sila (,,rimpull“) i brzina kretanja kamiona: Rm-maksimalno moguća vučna sila za postignutu brzinu kretanja na određenom segmentu; Ru-ostvarena vučna sila zapostignutu brzinu kretanja na određenom segmentu; v-brzina kretanja kamiona

Potrošnja goriva na određenom segmentu se računa preko formule: [7]

$$
\Delta f=\left[\frac{R_{U}}{R_{m}} \times \frac{\left(F_{100}-F_{0}\right)}{60}\right] \times \Delta t
$$

gde je:

$\Delta f$ - gorivo koje je potrošeno na određenom segmentu (l),

$R_{U} / R m$ - odnos ostvarene i maksimalne vučne sile za postignutu brzinu kretanja na određenom segmentu,

$F_{100}$ - potrošnja goriva kod $100 \%$ iskorišćenja snage motora $(1 / \mathrm{h})$,
$F_{0}$ - potrošnja goriva pri radu ,u prazno“, prim. čekanje kamiona na utovar (1/h),

$\Delta t$ - vreme kretanja kamiona na određenom segmentu.

Potrošnja goriva na svakom segmentu, kumulativno predstavlja ukupnu potrošnju goriva za transportnu relaciju. Prosečna časovna potrošnja goriva je data sledećom formulom: [7]

$$
F=\left(f_{t} \times N_{\text {trips }}\right)+\left[60-\left(N_{\text {trips }} \times T_{\text {travei }}\right) \times \frac{F_{0}}{60}\right]
$$


Gde je:

$$
\begin{aligned}
& F-\text { prosečna časovna potrošnja } \\
& \text { goriva (l/h), } \\
& f_{t}-\text { ukupna potrošnja goriva za trans- } \\
& \text { portnu relaciju (l), } \\
& \mathrm{N}_{\text {trips }}-\text { broj transportnih ciklusa na sat, } \\
& \mathrm{T}_{\text {travel }} \text { - vreme transportnog ciklusa (min). }
\end{aligned}
$$

\section{Simulacija kamionskog transporta u zavisnosti od lokacije primarnog drobljenja}

Simulacija kamionskog transporta je izvršena primenom softvera Talpac za prve dve godine u kojima se vrši otkopavanje rude, tj. za drugu i treću godinu prema projektovanoj dinamici otkopavanja.

Simulacija je izvršena sa sledećim ulaznim podacima:
- za materijal su uzeti podaci za rudu, tj. zapreminska masa od 2,65 t/ $\mathrm{m}^{3}$,

- za radno vreme na kopu (Roster) uzeto je $5.688 \mathrm{~h} / \mathrm{god}$, odnosno $5.206 \mathrm{~h} / \mathrm{god}$ za transportnu mehanizaciju,

- transportna relacija (Haul Cycle) je definisana unošenjem segmenata odgovarajućih dužina, nagiba, krivina skretanja i prosečnih brzina kretanja kamiona na kopu (slika 7),

- za utovarnu mehanizaciju na rudi u ovim godinama izabran je bager TEREX O\&K - RH 120 zapremine kašike $15 \mathrm{~m}^{3}$,

- za transportnu mehanizaciju izabrani su kamioni BELAZ 7513 nosivosti 136 t, KOMATSU HD 1500-5 nosivosti $150 \mathrm{t}$ i BELAZ 75306B nosivosti $220 \mathrm{t}$

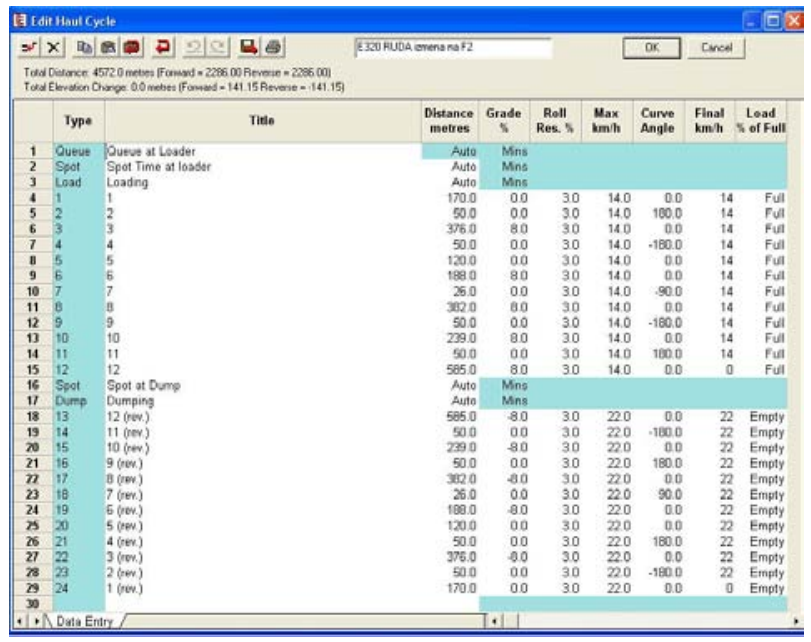

S1. 7. Unos segmenata transportne relacije za etažu E320

$\mathrm{Na}$ slici 7. prikazan je transportni ciklus (Haul Cycle) za etažu E320 koji se sastoji od ciklusa utovara, ciklusa vožnje punog kamiona i ciklusa istovara, takođe i u suprotnom smeru za kretanje praznog kamiona, na transportnoj relaciji koja je uneta u segmentima.

$\mathrm{Na}$ rezultat proračuna bitno utiču i eksploataciono - tehničke karakteristike izabrane opreme. Ove karakteristike su deo standardne baze podataka u Talpaku koju program koristi prilikom proračuna. Talpac poseduje bazu podataka o većem broju kamiona koji su u primeni, a u slučaju da se kamion ne nalazi u bazi, postoji mogućnost dopune za novu mehanizaciju.

Na slici 8. je prikazan dijagram odnosa opterećenja (vučnih sila) koja se stvaraju prilikom kretanja kamiona i brzina kretanja 
za slučaj kamiona KOMATSU HD 1500-5, nosivosti 150 t. Dijagram (preuzet iz baze podataka Talpaka) pokazuje logičan trend opadanja brzine kretanja kamiona sa porastom opterećenja pri kretanju. Preko ovih podataka program određuje brzine kretanja kamiona koje je moguće ostvariti na segmentima transportnih relacija koje su pod usponom, što konačno utiče na eksploatacioni kapacitet kamiona.

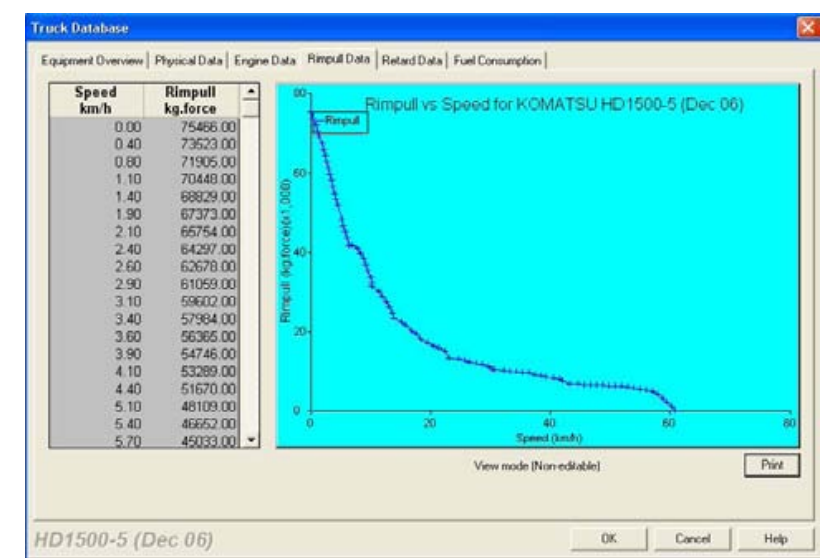

Sl. 8. Odnos vučnih sila i brzina kretanja kamiona KOMATSU HD 1500-5

Na slici 9 prikazan je grafik koji pokazuje zavisnost potrošnje goriva od opterećenja prilikom kretanja kamiona. Potrošnja goriva je proračunata preko specifične potrošnje goriva, koja je preuzeta od proizvođača i uneta u tabelu (gornji levi ugao slike 9), uzimajući u obzir i opterećenje motora kamiona pri kretanju, tj. kretanje pri usponu, odnosno padu.

Kako se to može videti sa dijagrama na slici 9, potrošnja goriva opada pri usporavanju (kretanju po padu), odnosno povećava se pri ubrzanju kamiona (kretanju po usponu).

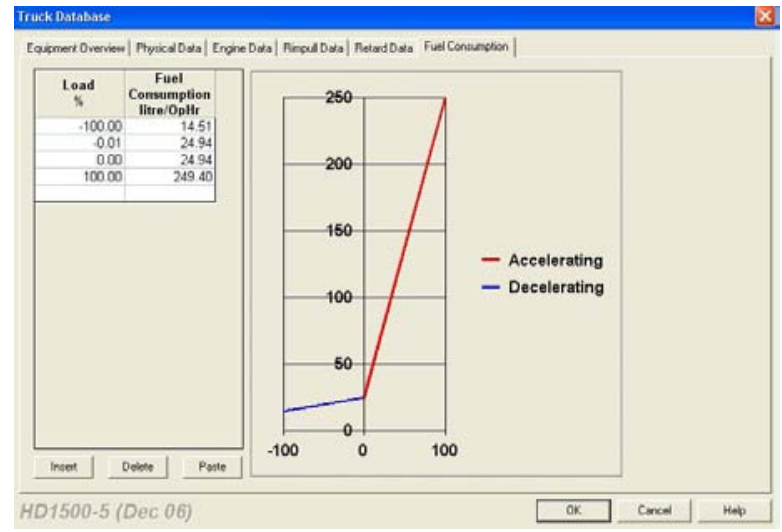

Sl. 9. „Prozor“ za unos podataka o potrošnji goriva

$\mathrm{Na}$ bazi unetih podataka o potrošnji goriva pri određenom režimu rada motora kamiona, program izračunava normativ potrošnje goriva za razmatranu relaciju. 


\section{Rezultati simulacije}

Na slici 10 su prikazani rezultati simulacije za određenu etažu (u ovom slučaju etaža E320), tj. eksploatacioni kapacitet kamiona i potrošnja goriva za tu transportnu relaciju. Normativ ulja i maziva usvojen je kao $10 \%$ od potrošnje goriva, dok je normativ guma proračunat $u$ zavisnosti od dobijenog eksploatacionog kapaciteta i veka trajanja guma koji je usvojen na $4.800 \mathrm{Mh}$.

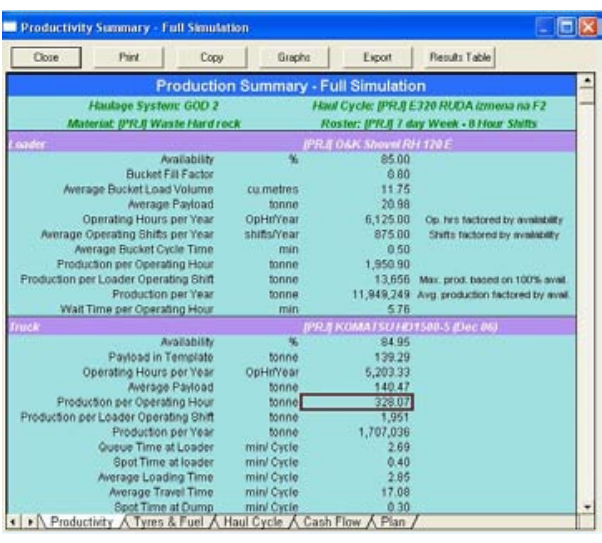

$a$.

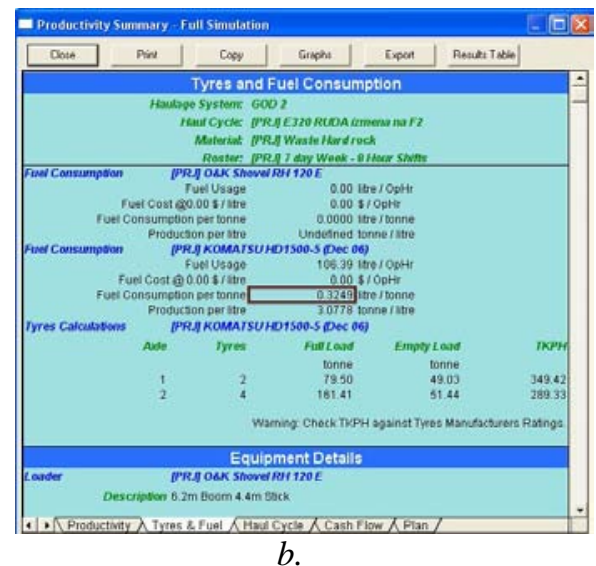

b.

Sl. 10. Rezultat simulacije (a. - eksploatacioni kapacitet, $b$. - normativ goriva)

U tabeli 1 je prikazan primer proračuna transporta za drugu godinu eksploatacije, za slučaj transporta rude prema drobiličnom postrojenju Faze 2 (lokacija B). Eksploatacioni kapaciteti i normativi potrošnog materijala su proračunati za svaku relaciju (etažu) posebno, dok su za konačne rezultate za ovu godinu uzete srednje ponderisane vrednosti. Potreban broj kamiona je dobijen kao količnik planirane godišnje proizvodnje na rudi i godišnjeg kapaciteta jednog kamiona.

U drugoj godini, zbog manjih količina na rudi, simulacija je izvršena samo za kamione KOMATSU nosivosti 150 t. Rudnik bakra Majdanpek (RBM) poseduje 2 kamiona ovog tipa što zadovoljava proračunom dobijen potreban broj kamiona.

U trećoj godini se javljaju veće količine rude, a samim tim je potreban i veći broj kamiona. Simulacija za ovu godinu je izvršena uzimajući u obzir poznat broj kamiona koje RBM poseduje, tj. 2 kamiona
KOMATSU, nosivosti 150 t i 3 kamiona BELAZ, nosivosti 136 t, kojima je dodat nepoznat (traženi) broj kamiona BELAZ, nosivosti 220 t, koji je potreban za zadovoljenje projektovanog kapaciteta. Rezultat proračuna je pokazao da je pored poznatog broja kamiona nosivosti 136 t i 150 t, potreban još jedan kamion nosivosti $220 \mathrm{t}$ da bi se ostvario planirani kapacitet na transportu, $\mathrm{tj}$. ukupno potreban broj kamiona je 6. Postupak proračuna za treću godinu, za slučaj transporta rude do Faze 2, prikazan je u tabeli 2. Eksploatacioni kapaciteti i normativi potrošnog materijala po etažama, koji su prikazani u tabeli 2, predstavljaju srednje ponderisane vrednosti dobijenih rezultata za pojedinačne kamione.

Postupak proračuna za drugu lokaciju drobljenja (lokacija A) u drugoj i trećoj godini je identičan prikazanom u tabelama 1 i 2, tako da nema potrebe za prikazom tabela za ovu lokaciju, već će konačni rezultati za tu lokaciju biti prikazani u tabeli 3 . 
U tabeli 3. uporedno su prikazani rezultati za drugu i treću godinu dinamike otkopavanja za lokacije primarnog drobljenja A i B. Zbog kraćih transportnih relacija za lokaciju B (Faza 2) dobija se nešto veći eksploatacioni kapacitet, a time i manji normativ na gumama. Sa druge strane, zbog potrebe savlađivanja većeg uspona za ovu lokaciju povećana je potrošnja goriva. Potreban broj kamiona u ova dva slučaja, za ove dve godine, nije promenjen.

Tabela 1. Rezultati proračuna za DRUGU godinu za transport rude do Faze 2 (lokacija B)

\begin{tabular}{|c|c|c|c|c|c|c|c|c|c|c|c|}
\hline Sprega & God & Etaža & Rudat & $t / h$ & h/god & $\begin{array}{c}\text { Br. } \\
\text { kamiona }\end{array}$ & $\begin{array}{c}\text { Relacija } \\
\mathrm{km}\end{array}$ & $t k m$ & $\begin{array}{c}\text { Nafta } \\
l / t\end{array}$ & $\begin{array}{c}\text { Ulja } i \\
\text { maziva } \\
\text { l/t }\end{array}$ & $\begin{array}{l}\text { Gume } \\
\text { kom/t }\end{array}$ \\
\hline 1 & 2 & 3 & 4 & 5 & 6 & 7 & 8 & 9 & 10 & 11 & 12 \\
\hline \multirow{6}{*}{$\begin{array}{c}\text { Bager } \\
15 \mathrm{~m}^{3}- \\
\text { Kamion }^{-} \\
150 \mathrm{t}\end{array}$} & \multirow{5}{*}{2.} & E380 & 27732 & *464,94 & 5206 & 0,01 & 1,441 & 39961 & 0,2157 & 0,02157 & 0,0000021 \\
\hline & & E365 & 551537 & 478,78 & 5206 & 0,2 & 1,368 & 754503 & 0,2103 & 0,02103 & 0,0000020 \\
\hline & & E350 & 1104511 & 398,96 & 5206 & 0,5 & 1,735 & 1916327 & 0,2536 & 0,02536 & 0,0000024 \\
\hline & & E335 & 1526107 & 339,97 & 5206 & 0,9 & 2,128 & 3247555 & 0,2994 & 0,02994 & 0,0000028 \\
\hline & & E320 & 575510 & 327,44 & 5206 & 0,3 & 2,286 & 1315616 & 0,3250 & 0,0325 & 0,0000029 \\
\hline & \multicolumn{2}{|c|}{ Total } & 3785397 & 376,418 & 5206 & 1,9 & 1,9216 & 7273963 & 0,2763 & 0,02763 & 0,0000026 \\
\hline
\end{tabular}

Tabela 2. Rezultati proračuna za TREĆU godinu za transport rude do Faze 2 (lokacija B)

\begin{tabular}{|c|c|c|c|c|c|c|c|c|c|c|c|}
\hline Sprega & God & Etaža & Rudat & $t / h$ & h/god & $\begin{array}{c}\text { Br. } \\
\text { kamiona }\end{array}$ & $\begin{array}{c}\text { Relacija } \\
\mathrm{km}\end{array}$ & tkm & $\begin{array}{c}\text { Nafta } \\
\mathrm{l} / \mathrm{t}\end{array}$ & $\begin{array}{c}\text { Ulja } i \\
\text { maziva } \\
\text { l/t }\end{array}$ & $\begin{array}{l}\text { Gume } \\
\text { kom/t }\end{array}$ \\
\hline 1 & 2 & 3 & 4 & 5 & 6 & 7 & 8 & 9 & 10 & 11 & 12 \\
\hline \multirow{7}{*}{$\begin{array}{l}\text { Bager } \\
15 \mathrm{~m}^{3} \text { - } \\
\text { Kamioni } \\
136 \mathrm{t} \text {, } \\
150 \mathrm{ti} \\
220 \mathrm{t}\end{array}$} & \multirow{6}{*}{3.} & E320 & 1022074 & 313,637 & 5206 & 0,5 & 2,511 & 2566428 & 0,3071 & 0,03071 & 0,0000031 \\
\hline & & E305 & 1607407 & 276,520 & 5206 & 1,1 & 2,874 & 4619689 & 0,3532 & 0,03532 & 0,0000035 \\
\hline & & E290 & 1665957 & 276,153 & 5206 & 1,2 & 2,847 & 4742979 & 0,3640 & 0,03639 & 0,0000035 \\
\hline & & E275 & 1691960 & 269,713 & 5206 & 1,2 & 2,89 & 4889765 & 0,3857 & 0,03856 & 0,0000036 \\
\hline & & E260 & 1672198 & 254,543 & 5206 & 1,3 & 3,103 & 5188831 & 0,4192 & 0,04192 & 0,0000038 \\
\hline & & E245 & 875609 & 244,910 & 5206 & 0,7 & 3,261 & 2855,362 & 0,4492 & 0,04491 & 0,0000039 \\
\hline & \multicolumn{2}{|c|}{ Total } & 8535206 & 271,995 & 5206 & 6,0 & 2,91 & 24863055 & 0,3790 & 0,03790 & 0,0000035 \\
\hline
\end{tabular}

Tabela 3. Uporedni prikaz rezultata za obe lokacije primarnog drobljenja rude za različite tipove kamiona

\begin{tabular}{|c|c|c|c|c|c|c|c|c|}
\hline $\begin{array}{c}\text { Godina / } \\
\text { Period }\end{array}$ & $\begin{array}{l}\text { Utovarno- } \\
\text { transportna } \\
\text { sprega }\end{array}$ & $\begin{array}{c}\text { Lokacija } \\
\text { drobiličnog } \\
\text { postrojenja }\end{array}$ & $\begin{array}{c}\text { Prosečna } \\
\text { duťina } \\
\text { relacije, } \\
\mathrm{km}\end{array}$ & $\begin{array}{c}\text { Prosečni } \\
\text { eksploatacioni } \\
\text { casovni kapacitet, } \\
\text { th }\end{array}$ & $\begin{array}{c}\text { Normativ } \\
\text { goriva, } \\
\qquad t\end{array}$ & $\begin{array}{l}\text { Normativ } \\
\text { ulja } i \\
\text { maziva, } V_{t}\end{array}$ & $\begin{array}{l}\text { Normativ } \\
\text { guma, } \\
\text { kom/t }\end{array}$ & $\begin{array}{l}\text { Potreban } \\
\text { broj } \\
\text { kamiona }\end{array}$ \\
\hline \multirow{2}{*}{ God. 2.} & \multirow{2}{*}{$\begin{array}{l}\text { Bager } 15 \mathrm{~m}^{3}- \\
\text { Kamioni } 150 \mathrm{t}\end{array}$} & $\mathbf{A}$ & 2,06 & 359,23 & 0,2082 & 0,02082 & 0,0000027 & 2 \\
\hline & & B & 1,92 & 376,42 & 0,2763 & 0,02763 & 0,0000026 & 2 \\
\hline \multirow{2}{*}{ God. 3.} & \multirow{2}{*}{$\begin{array}{l}\text { Bager } 15 \mathrm{~m}^{3}- \\
\text { Kamioni } 136 \mathrm{t} \text {, } \\
150 \mathrm{t} \mathrm{i} 220 \mathrm{t}\end{array}$} & $\mathbf{A}$ & 2,91 & 271,95 & 0,3790 & 0,03790 & 0,0000035 & 6 \\
\hline & & B & 2,57 & 280,25 & 0,3927 & 0,03927 & 0,0000034 & 6 \\
\hline
\end{tabular}

\footnotetext{
*U tabelama 1 i 2, u kolonama 5. i 10. - eksploatacioni kapacitet $(t / h)$ i normativ potrošnje nafte $(1 / t)$ za relaciju na određenoj etaži, dati su rezultati iz analize u Talpac-u, dok su ostali podaci delom ulazni (količine rude), a delom izvedeni ponderisanjem i sračunati na osnovu rezultata iz simulacije u Talpac-u. Npr. broj kamiona za određenu etažu sračunat je kao količnik proizvoda kolona 5. i 6. $i$ kolone broj 4., tj $(5 * 6) / 4$.
} 


\section{ZAKLJUČAK}

Primenom klasične metode proračuna transporta, u kojoj se ne uzimaju u obzir karakteristike transportnih relacija, za kraće transportne relacije bi se takođe dobili veći eksploatacioni kapaciteti ali, sa druge strane, i manje vrednosti normativa što ovde nije slučaj.

Primenom softvera za simulaciju utovarno-transportnih sprega, u ovom slučaju softvera Talpac, moguće je doneti odluku na bazi preciznije dobijenih rezultata nego što je to slučaj kod primene klasične metode proračuna. Takođe, jednom urađena simulacija se može više puta preračunati, izmenom ulaznih parametara poput vrste utovarne i transportne opreme, transportnih relacija, brzina kretanja kamiona i planirane organizacije rada.

Sa druge strane, da bi se iskoristila mogućnost dobijanja što preciznijih rezultata simulacije, potrebno je da se transportna relacija detaljnije obradi, tj. unese $u$ segmentima za svaki uspon, pad i skretanje. Ovim se povećava vreme potrebno za proračun transporta $\mathrm{u}$ odnosu na klasičnu metodu u kojoj se ovo obično ne radi.

\section{LITERATURA}

[1] D. Kržanović i dr.: Studija izvodljivosti eksploatacije ležišta Južni revir u rudniku bakra Majdanpek, Institut za rudarstvo i metalurgiju Bor, 2011

[2] D. Kržanović, M. Žikić, N. Vušović, R. Pantović, S. Stojadinović: Optimum Development of the Open Pit South Mining District in Majdanpek for
Annual Capacity of Copper Ore Mining of $8500000 \mathrm{t}$, The $44^{\text {rd }}$ International October Conference on Mining and Metallurgy, Hotel Albo Bor, 1-3 oktobra 2012, str. 225-228

[3] D. Kržanović, M. Žikić, R. Pantović: Bitno poboljšanje iskorišćenja raspoloživih geoloških rezervi ležišta Južni revir Majdanpek u novo definisanoj optimalnoj konturi kopa primenom softverskih paketa Whittle i Gemcom, Rudarski radovi 1/2012, str. 21-28

[4] D. Kržanović, M. Žikić, S. Stojadinović: Analiza ostvarene i kataloške potrošnje goriva kamiona Belaz 7530b u prvoj godini eksploatacije na površinskom kopu Veliki Krivelj, Integrated International Symposium Tiorir '11, Proceedings, Volume 1, Zlatibor, Srbija, 11-15 septembra 2011, str. 6064

[5] V. Malbašić, J. Hamović: Economic Evaluation of Haulage System Shovel - truck on the Open Pit Mines, The International Journal of Transport and Logistics, iss. 7, pp. 17-31, 2004

[6] R. Janković, Lj. Savić: Simulation of Truck Haulage at the Open Pit Mine Majdanpek, Transport i logistika, iss. 11, pp. 96-103, 2006

[7] Talpac Manual: TALPAC Truck and Loader Productivity Analysis, Release 9, 2007

[8] S. Mašić, M. Brčaninović, Analiza parametara rada kamiona БелА3 na površinskim kopovima RMU "Banovići" na osnovu podataka sa procesora, Mining and Metallurgy Institute Bor, 4/2013, str. 39-48 